Wojciech Zyzak

The Pontifical University of John Paul II in Krakow, Poland

\title{
Mercy as a Theological Term
}

\begin{abstract}
The author of the article analyses different meanings of the term 'mercy'. He begins with the ancient use of the word by pagan philosophers. This is the background for the analysis of the term 'mercy' in the Old and New Testament. The biblical sources lead to the definition of dogmatic foundations of God's Mercy and allow the ethical and moral aspects of the human mercy to be shown. Closely connected with the last is the social dimension of the mercy. The author also deals with other dimensions of the mercy, such as: pastoral, liturgical, psychological and juridical. He also discusses the meaning of the mercy in the spirituality and Christian art.
\end{abstract}

\section{Keywords}

Mercy; Bible; spirituality.

\section{Introduction}

Terry A. Veling wrote: "I recently spent a few evenings searching the indexes of my books, looking for entries on 'mercy'. I was surprised at the paucity of references, though when I looked up 'justice', entries abounded. It seems that mercy is a rather silent word and perhaps - of its nature - does not draw attention to itself"'. Nevertheless, the topic is not a new one beyond the Catholic theology too. In 1839 John Cox wrote: "Everything connected with

1 T. A. Veling, In the Name of Mercy: A Meditative Exploration, "Pacifica-Australasian Theological Studies" 22 (June 2009), p. 215. 
the religion of the Bible, is imbued with mercy. God is a God of mercy; Jesus is the mercy promised; and saints are vessels of mercy"2.

One of the characteristics of Catholic theological thought during the pontificate of Saint John Paul II was the intensification of interest in the subject of mercy, due to the papal teaching, especially in Encyclical Letter Dives in misericordia and popularization of the cult of Divine Mercy in the form revealed to Saint Sister Faustina Kowalska3. "It is 'God, who is rich in mercy' whom Jesus Christ has revealed to us as Father: it is His very Son who, in Himself, has manifested Him and made Him known to us". With these words John Paul II begins his Encyclical Letter. This is the foundation of theological reflection on mercy, which, however, must be carried out in different aspects. Mercy is a subject of interest for biblistics, dogmatics, moral theology, spirituality, pastoral theology, liturgics and canon law. Each of these fields deals with mercy in their own, but ultimately complimentary, way.

\section{Mercy according to ancient pagan philosophers}

Mercy, as an idea, is not unknown to the pre-Christian thought. It is possible to trace the evolution of its understanding by ancient pagan philosophers, beginning with a very positive one by Homer, ending with its treatment as a vice by Aristotle and the stoics. Mercy was only accepted as a sympathy to human suffering, especially in hopeless situations, for instance in terminal illness, but Plato maintained that a judge should not be directed by mercy. Aristotle assessed it even more skeptically, because for him it was an emotional reaction and therefore immature. For him, it was not a virtue but a vice allowed only for the elderly, women and children. In his opinion, a mature person should be directed by the mind and be in control of all emotional reactions. The stoics considered merciful compassion even as an illness of the soul (aegritudo animi). Cicero maintained that mercy was more a vice than a virtue because it brings pain. It should be shown only to those suffering unjustly and discriminated by law. Sometimes, however, mercy was praised by him as a virtue worthy of the p. IV.

2 J. Cox, Divine Mercy; or, the Riches of God's Pardoning and Paternal Love, London 1838,

3 J. Zabielski, Wydobywanie dobra. Teologia chrześcijańskiego miłosierdzia, Białystok 2006, p. 11. 
highest admiration (ProLigario) and a sign of wisdom and morality (ProMurena). In a similar way, Seneca taught that misericordia, as an emotional condition, disturbs mental stability and interferes with a just decision on the punishment for the guilty. However, in his writings, one can also find a positive meaning of mercy (De beneficiis) $)^{4}$. His tract "On mercy" (De clementia), addressed to Nero, urges that Stoicism need not be construed as an overly harsh doctrine 5 . Mercy is a very important part of Roman Stoicism ${ }^{6}$.

\section{Mercy in the Old and New Testament}

It is obvious that the pagan philosophers, with their vocabulary, have not had such an immense impact on theologians dealing with mercy, as the Bible has. In the Bible, mercy is a quality of showing compassion. This quality enables God to show compassion toward the guilty and the distressed (Deut $4: 31$ ). God shows compassion toward the sinners by temporarily withholding the punishment they deserve (Neh 9:17; Jer 33:23-26, Rom 11:30-32; Eph 2:4, Tit $3: 5)$. However, God's mercy toward the wicked is not endless. In time, God will judge those who fail to respond positively to His general revelation in nature (Rom 1:18-20) and to those who reject His special revelation of Salvation in Christ (Rom 2:8-9; John $3: 36$ ). In mercy, God shows compassion toward those who suffer or who are in distress. He grants them relief (Ps 104:8-18; Is $49 ; 13$; Heb. $4: 16$; Jas $5: 11)$. According to the Bible, not only should we be grateful to God for His mercy on us, but we should also show this mercy to others (Mt 5:7; Col 3:12). We can do what is pleasing to God only with the help of the Holy Spirit?

In the Old Testament "mercy" is used as the translation of three Hebrew words, the most common one being "hesed". It is the covenantal love between Abraham and Sarah (Gen 20:13), David and Jonathan (1 Sam 20:8), and Yahweh and the people (Ex 20:6). It is mutual and enduring, implying action

4 J. Zabielski, Wydobywanie dobra, p. 67-71.

5 N. Sherman, Stoic Warriors: The Ancient Philosophy Behind the Military Mind, Oxford 2005, p. 14.

6 M. C. Nussbaum, Philosophical norms and political attachments: Cicero and Seneca, in: Body and Soul in Ancient Philosophy, ed. D. Frede, B. Reis, Berlin 2009, p. 438.

7 F. H. Barackman, Practical Christian Theology: Examining the Great Doctrines of the Faith, Grand Rapids MI 2001, p. 58. 
on both parts. The next word is "Rahamim", the plural form of "womb", and this is also translated as "mercy". God's mercy is a nurturing womb, implying a physical response and demonstrating that mercy is felt in the center of one's body. This dimension of mercy also requires action. Also translated as "mercy" is the Hebrew word "hen" or "henan", meaning "grace" or "favor". Unlike the terms already mentioned above, this is a free gift, with no mutuality either implied or expected. Not necessarily enduring, this quality is dependent solely on the giver and usually occurs between unequals. Taken together, these three Hebrew words and their meanings give us an understanding of God's mercy in the Old Testament. It is best demonstrated by Hosea and Jeremiah, who use the analogy of marriage between Yahweh and Israel, showing us that mercy is the fruit of the covenant, forgiving as well as caring and nurturing.

The same aspect of mercy was underlined by Pope John Paul II in his Encyclical Letter "Dives in misericordia" no. 4: "In describing mercy, the books of the Old Testament use two expressions in particular, each having a different semantic nuance. First there is the term hesed, which indicates a profound attitude of 'goodness'. (...) The second word which in the terminology of the Old Testament serves to define mercy is rahamim. This has a different nuance from that of hesed. While hesed highlights the marks of fidelity to self and of 'responsibility for one's own love' (which are in a certain sense masculine characteristics), rahamim, in its very root, denotes the love of a mother (rehem $=$ mother's womb). From the deep and original bond - indeed the unity - that links a mother to her child there springs a particular relationship to the child, a particular love. Of this love one can say that it is completely gratuitous, not merited, and that in this aspect it constitutes an interior necessity: an exigency of the heart. It is, as it were, a 'feminine' variation of the masculine fidelity to self expressed by hesed".

In the New Testament the most commonly used semantic group expressing mercy is the verb $\dot{\varepsilon} \lambda \varepsilon \dot{\varepsilon} \omega$ and deriving from it the noun $\varepsilon \dot{\lambda} \varepsilon \mathrm{\varepsilon}$. As a noun it means mercy and is most often equivalent to Hebrew root hesed. Another semantic group is $\sigma \pi \lambda \alpha \gamma \chi v$, which emphasizes feelings of emotion and pity, certainly due to a connection with entrails (splanchna). The next group oik $\tau i ́ p \omega$ is related to rahamim and expressing tenderness, emotion and sincere empathy, most frequently it refers to God. In the New Testament mercy is understood

8 J. Upton, Mercy, in: The New Dictionary of Catholic Spirituality, ed. M. Downey, Collegeville 1993 , c. 653 n. 
in relation to the person and the work of Jesus Christ, especially His Paschal Mystery. The truth of Divine Mercy is the most important content of Christ's teaching and the crucial motive of His redemption?.

\section{Dogmatic-systematic foundations of Mercy}

Dogmatic Catholic theology bases its considerations on Divine Mercy, above all, on the Bible. In this case, Mercy is understood as, undeserved and totally free act of God's turning to the creation. It does not mean an attribute of God's essence, butrelated to grace, taken from a historical-redemptive perspective, it is an expression of His essential love. God manifests His Mercy by turning to the suffering with tenderness and to the sinners with forgiveness. It is because of this that the Mercy exists in a relationship of tension with justice. If justice is to give each his due, it is obvious that such a giving from God is always undeserved and comes from Mercy ${ }^{10}$.

Mercy as a major motive of God's work was the subject of the considerations of various Church Fathers (Augustine of Hippo, John Chrysostom, Peter Chrysologus) and of medieval theologians (Bernard of Clairvaux and Thomas Aquinas) ${ }^{11}$. Scholastics traditionally differentiated between attributes that belong to Him as God in His essence (simplicity, infinity, eternity, immutability), from relational ones, which are shown in God's works for creation (wisdom, goodness, providence, justice, mercy). Through the analogy to human spiritual powers it was said that the attributes of wisdom and providence are anchored in God's mind, whereas goodness, justice and mercy are connected to His will. Mercy is understood here as an act of God's goodness granted to the person with the purpose of liberation from weakness ${ }^{12}$. Without diminishing God's immutability, it assumes a kind of compassion. The theological tradition talks

9 I. Broer, Barmherzigkeit. I. Biblisch, in: Lexikon für Theologie und Kirche, v. II, Freiburg im Breisgau 2006, c. 14n; J. Zabielski, Wydobywanie dobra..., p. 53. 63n.

${ }^{10}$ Por. E. Salmann, Barmherzigkeit. II. Systematisch-theologisch, in: Lexikon für Theologie und Kirche, v. II, Freiburg im Breisgau 2006, c. 15.

${ }^{11}$ M. J. Scheeben, Handbuch der Katholischen Dogmatik, v. IV, Freiburg 1948, p. 264-271.

12 J. Machniak, Doświadczenie Boga w tajemnicy Jego miłosierdzia u Bt. Siostry Faustyny Kowalskiej, Kraków 1998, p. 16. 
about Divine Mercy as infinite, as being an attribute of God's infinite nature and a fruit of His infinite love. It is the major motive of God's external acting ${ }^{13}$.

What is more, in the revelations of Saint Faustina Kowalska, Divine Mercy is defined as "the biggest attribute of God"14. Saint Thomas asked if mercy was the greatest attribute of God. In his opinion, since God is the absolute superior, the perfect and self-existent creator, He is never self-seeking, but acts only and always with selfless generosity, pouring out good gifts out of His abundance on His creatures. Showing mercy is therefore proper to God in a special way, for it manifests His infinite perfection, and His infinite abundance and generosity. But if we consider a virtue in terms of its possessor, we can say that mercy is the greatest of the virtues only if its possessor is himself the greatest of all beings, with no one above him and everyone beneath him. This, of course, is properly true only of God Himself. Thus, mercy is, in that sense, the greatest attribute of $\mathrm{God}^{15}$.

Considerations on Divine Mercy in the Trinitarian dimension take on a Christological character due to the fact that its most complete revelation is the mystery of incarnation which culminates in the death and resurrection of $\mathrm{Christ}^{16}$. Jesus is the most eloquent witness to mercy in the New Testament. He is never vague in His proclamation of God's mercy, and rather than using parables or discourses, He reveals God's mercy in His everyday relations with people. Jesus is an active agent of God's mercy when He confronts the crowd about to stone the woman taken in adultery, meets the Samaritan woman at the well, weeps with the other mourners at the death of Lazarus, and ultimately when He takes up the cross laden with the sins of the world and is led to His death ${ }^{17}$. This is also the basis for an ecclesiological reflection on God's Mercy: the Church, being the fruit of Pascal Mystery, not only preaches and confesses mercy, not only tries to recall and imitate it, but realizes and makes it present as sacrament of salvation. It is the Channel of God's eternal Mercy

13 J. Machniak, Doświadczenie Boga, p. 17n.

${ }^{14}$ W. Słomka, Miłosierdzie Boże, in: Leksykon Duchowości Katolickiej, Lublin-Kraków 2002, p. 523 .

15 Thomas Aquinas, Summa theologica, II-II, q. 30, a. 4.

${ }^{16}$ A. Słomkowski, Miłosierdzie Boże we Wcieleniu i Odkupieniu, in: Ewangelia Miłosierdzia, ed. W. Granat, Poznań 1970, p. 49-112.

17 J. Upton, Mercy, in: The New Dictionary of Catholic Spirituality, ed. M. Downey, Collegeville 1993, c. 654. 
for the world ${ }^{18}$. This ecclesiological reflection has to find its continuation in the sacramentological reflection. When analyzing the most profound nature of sacrament i.e. Christ's life, death and resurrection made present in liturgy, one approaches the mystery of God, the Father of mercies $^{19}$. It particularly concerns the baptism, Eucharist and the sacrament of penance, in which a meeting takes place with the merciful and sin-forgiving $\mathrm{Christ}^{20}$.

\section{Ethical and moral aspects of mercy}

The moral theology is interested in mercy mainly in the aspect of human relations. Here mercy is a form of love, which spontaneously turns to someone in need of help. A merciful person suffers in solidarity with a neighbour and tries to remove everything impeding their development. An example of such an attitude was shown by Christ in the parable of the Good Samaritan (Lk 10, $33 n$ ), who noticed, sympathized and took definite action to help a victim. In the teaching of the Fathers of the Church, mercy occupies a central place not only because of the duty to be charitable, but also because of its objective value: the resulting charitable person and the importance for the community. Saint Thomas Aquinas considered mercy as a moral virtue. Although its objects are feelings, its source is an intellectual-volitional ability and is close to love having another source in human misery. Emphasis on the element of compassion in the scholastic theology has resulted in the separation of mercy from love and from works of mercy as well. In such a vision, the works of mercy are not considered as acts of the Church and its social importance is not appreciated. Emphasis on the works of mercy has overshadowed the interpretation of mercy as a virtue. In this concept, the essence of mercy is reduced due to identification with works and acts, thus exhibiting the act of a benefactor and avoiding the importance of the act itself and the beneficiary. Critics of this view underline the fact that the final cause of mercy is not misery but the imitation of God's Mercy, and the dignity of a human person.

${ }^{18}$ L. Balter, Kościól jako sakrament Bożego Miłosierdzia, in: Kolekcja Communio, nr 15, Bóg bogaty w miłosierdzie, Poznań 2003, p. 173.

${ }_{19}$ N. Bux, Miłosierne działanie Trójcy Świętej w sakramentach, in: Kolekcja Communio, nr 15, Bóg bogaty w miłosierdzie, Poznań 2003, p. 196.

${ }^{20}$ S. Mojek, Miłosierdzie Boże w sprawowaniu sakramentu pojednania, in: Homo Meditans, v. 5, Miłosierdzie w postawie ludzkiej, ed. W. Słomka, Lublin 1989, p. 130-134. 
In post-Tridentine theology, mercy has been reduced to alms. Of course, practicing the works of mercy has not so much a theological, but a huge practical importance ${ }^{21}$. According to Mt $25: 31-46$, mercy will be the quality on which the Christian will ultimately be judged. This understanding of the necessity of mercy was also developed in the early Church, particularly in the "Didache", which went so far as to state that those who have no mercy will be condemned. Traditionally, these instructions of the Gospel have been handed down to us as the corporal and spiritual works of mercy, which should characterize the lives Christians lead. The corporal works of mercy require the Christian to feed the hungry, give drink to the thirsty, clothe the naked, shelter the homeless, care for the sick, visit those imprisoned, and bury the dead. The spiritual works of mercy mean admonishing sinners, instructing the ignorant, counseling the doubtful, comforting the sorrowful, bearing wrongs patiently, forgiving injuries, and praying for the living and the dead. These build on the biblical foundation that one must "do justice, love mercy, and walk humbly with our God" (Mic 6, 8) $)^{22}$.

Mercy as an act of merciful love consists of the common experience of goodness of persons and of the common experience of their dignity. The attributes of mercy understood in this way are: joint participation in the goodness of the person, the reciprocal experience of this goodness, the recognition of the equality of all people of people whilst maintaining their ontological distinction and the fidelity to the person. In a full and proper meaning, mercy is realized in the relation of God to the person, but in an analogical way it is realized in the relations among people who imitate God "rich in mercy"23. Joint participation in the goodness of the person and their dignity, which is an essential attribute of the Christian idea of mercy, is possible only in reciprocity. Thus, the merciful love in all personal relations is always a mutual process. Reciprocity of goodness, experienced in mercy, is the basis of equality and interpersonal solidarity, and a way to authentic justice. Without the specific recognition of the equality brought by mercy, struggle for pure justice can become inhuman (summum ius summa iniuria). Mercy is the source and perfection of justice

${ }^{21}$ Thomas Aquinas, Summa theologica, II-II, q. 30, a. 3; J. Zabielski, Wydobywanie dobra..., p. 80. 83n; A. Elsässer, Barmherzigkeit. III. Theologisch-ethisch, in: Lexikon für Theologie und Kirche, t. II, Freiburg im Breisgau 2006, c. 15n.

${ }_{22}^{2}$ J. Upton, Mercy, in: The New Dictionary of Catholic Spirituality, ed. M. Downey, Collegeville 1993, c. 654.

23 J. Upton, Mercy, p. 105. 
because it is its ultimate fulfillment ${ }^{24}$. Besides these concrete forms of mercy, we must include the developing of the imagination of mercy and being real neighbors: an attitude of conversion towards the person and staying with them. The aforementioned attributes concern, to a large degree, the understanding of mercy in the Catholic social teaching ${ }^{25}$.

\section{The Social aspect of mercy}

It is clear that the New Testament presents the gospel of Jesus which includes social justice and mercy. Moreover, Old Testament morality provides a background to this gospel for it already articulates many of the necessary components for a just socioeconomic order, e.g., in the teachings of the prophets and the Ten Commandments ${ }^{26}$. However, "Jesus perfects and radicalizes these, by teaching a mercy which goes beyond what is usually regarded as justice. Love of neighbors, and even of enemies, demands, in practice, that those who accept God's loving kindness extend it to others in concrete ways"27.

The engagement of Christians in the service of mercy, beyond the individual dimension, often takes on the form of social and institutional activity. It is most precious when it is carried out voluntarily and not for profit. If this activity is undertaken with evangelical motivation, it is a form of apostolate ${ }^{28}$. The Church, throughout its history, has organized different kinds of mercy works, beginning with the service of deacons and material help for other communities through charitable activity of religious institutes, fraternities and hospitals in the Middle Ages, to the modern forms of Caritas organization ${ }^{29}$.

However, together with the immersion of the idea of welfare state in the 19th century which guaranteed social safety, it began to seem that mercy as a major social virtue was losing its importance. From that time mercy started to be associated with haughtiness, false pity or camouflage of neglected structural

24 J. Upton, Mercy, p. 178 n.

25 J. Upton, Mercy, p. 180.

${ }^{26}$ R. Charles, D. Maclaren, The Social Teaching of Vatican II: Its Origin and Development, San Francisco 1982, p. 48-56.

${ }_{27}$ G. Grisez, The Way of the Lord Jesus, v. 2: Living a Christian Life, Quincy 1993, p. 99.

${ }^{28}$ J. Zabielski, Wydobywanie dobra..., p. 171.

29 B. Ferdek, Mitosierdzie, in: Leksykon Duchowości Katolickiej, Lublin-Kraków 2002, p. 519-522. 
reforms. In Marxism it was especially emphasized that the poor do not need charitable help but justice. This is partly true, although it is necessary to add that, even where the state has institutionalized the right to social care to wide degree, there is still much room for spontaneous and voluntary help, which in many cases cannot be replaced ${ }^{30}$. Besides these most important misunderstandings which falsify the idea of mercy, we can add three others. Firstly, a purely individualistic attitude, which does not take the social context into account. Secondlya purely spiritual understanding of mercy, and lastly the persuasion, mostly in rich countries, that the works of mercy have lost importance, with the exception of help for poor countries ${ }^{31}$.

Ambivalence concerning mercy can be seen on the one hand in the attitude of indifference or animosity, and on the other hand in understanding it as a great calling of the world. The answer to this calling should take on different forms of merciful service such as the "imagination of Mercy" (John Paul II), being neighborly to the needy, removing layers of evil, trusting Divine Mercy and preaching it to the world. These are forms of acts of mercy known in the tradition of the Church $^{32}$. The evangelical example of the good Samaritan shows the characteristic for the Catholic social teaching method: see, judge, act, as especially useful in the practicing of mercy ${ }^{33}$.

In the culture based on Divine Mercy the question is to protect the human being as a person bestowed with inalienable dignity, reasonable and free, by their nature social, called to love, a subject and participant of God's plans. The life of man and mankind must develop on the foundation of common moral culture. That is why democracy should not take on, exclusively, an economical model of productivity and consumerism but it should undertake new common efforts to build a society able to share material and spiritual goods ${ }^{34}$. Here, mercy is particularly important, since, without it, the building and deepening of a civilization of love is not possible. In the face of the ideology of hate and class

${ }^{30}$ Benedict XVI, Deus caritas est, $\mathrm{nr} 26$; Caritas in veritate, nr 6. 79; A. Elsässer, Barmherzigkeit. III. Theologisch-ethisch..., c. 15n.

${ }^{31}$ J. Krucina, Komentarz do encykliki Jana Pawła II „Dives in misericordia”, in: Encyklika Ojca Świętego Jana Pawła II o Bożym Miłosierdziu „Dives in misericordia”, Wrocław 1996, p. 94.

32 J. Zabielski, Wydobywanie dobra..., p. 167.

${ }^{33}$ Kongregacja do Spraw Wychowania Katolickiego, Wskazania dotyczace studiów i nauczania doktryny społecznej kościoła w ramach formacji kapłańskiej, 1988, nr 7.

${ }^{34}$ P. Warchoł, Miłosierny Bóg i miłosierny człowiek. Teologiczna interpretacja miłosierdzia w nauczaniu Jana Pawła II, Wrocław 2007, p. 265n. 
struggle, Christianity proposes a real equality and internationalism expressed by Saint Paul in the Letter to Galatians $(3: 28)$. Perceiving human sinfulness, highlights the mystery of mercy from which flows the duty to give a helping hand in every situation ${ }^{35}$.

\section{Mercy in Christian spirituality}

In the early 1930's a young Polish nun, Sr. Faustina Kowalska, received extraordinary visions of Christ. Jesus spoke to her of His abundant Mercy and taught her to have total abandonment to Him, which is the inscription at the bottom of the image of Divine Mercy "Jesus, I Trust in You"36. Divine Mercy requires, above all, a response of an attitude of total confidence in the act of faith - it means trust ${ }^{37}$. An analysis of the Diary of Saint Faustina shows the need to become acquainted with the reality of Divine Mercy, to trust it, to pray for mercy, to praise God in this mystery and to develop an attitude of merciful love. Christian spirituality is interested in all these forms, but especially investigates signs of piety and worship of Divine Mercy ${ }^{38}$. Different forms of the worship of God rich in Mercy aim to glorify Him and bring people closer to Him, opening them to the grace which merciful Jesus wants to give to everybody. To the basic forms of worship taught by sister Faustina we add: veneration of the image of Divine Mercy, celebration of the feast of Divine Mercy, different prayers to the Divine Mercy especially the chaplet of the Divine Mercy, the novena and ejaculatory prayers said particularly at 3 p.m. Additionally, it must be mentioned that the reading of Diary can be a valuable source of meditation ${ }^{39}$. In number 754, the Lord promises: "The souls that say this chaplet will be embraced by My mercy during their lifetime and especially at the hour of their death".

Many saints have experienced a special spiritual bond with the mystery of Divine Mercy. Among them, worth mentioning, is Saint Faustina Kowalska, the "secretary" of Divine Mercy. Many saints also became famous through

35 A. Nossol, Personalistyczno-humanistyczny aspekt $w$ doznawaniu i świadczeniu miłosierdzia, in: Homo Meditans, v. 5, Miłosierdzie w postawie ludzkiej, ed. W. Słomka, Lublin 1989, p. 51.

${ }^{36}$ R. Torretto, A Divine Mercy Resource: How to Understand the Devotion to Divine Mercy, Bloomington 2010, p. 3.

37 J. Machniak, Doświadczenie Boga..., p. 21.

38 W. Słomka, Miłosierdzie Boże..., p. 523.

39 J. Machniak, Doświadczenie Boga..., p. 279. 288. 
The Person and the Challenges
Volume 5 (2015) Number 1, p. 137-153

acts of mercy, a special example of which, in Polish spirituality, is Saint Albert $\mathrm{Chmielowski}^{40}$. From the above, it results that holiness, which is the aim of every true spirituality, is essentially connected with mercy. In Christian spirituality it is thus very meaningful that many religious communities refer in their name and spirituality to the mystery of Divine Mercy ${ }^{41}$.

\section{Mercy in Christian art}

The spirituality of mercy has found its expression in Christian art for centuries. Just as in liturgy, the rule lex orandi lex credendi defines the bond of prayer and faith, so too in Christian art the forms of presentation of mercy show the state of faith in a certain age and place. For centuries, mercy has been presented above all in the form of works of mercy. There are seven corporal works of mercy: to feed the hungry, to give drink to the thirsty, to clothe the naked, to visit the sick, to visit prisoners, to harbor strangers, and to bury the dead. In Matthew $25: 34-45$, Christ lists all these works except burying the dead. In Tobit 12:13, when the Archangel Raphael reveals his identity to Tobit, he says "when you did not hesitate to get up and leave your dinner to go and bury the dead". This reference to the seventh work of mercy is the Old Testament completion of Christ's New Testament list ${ }^{42}$.

In Matthew 25:31-46 there are six corporal works of mercy. Probably Lactantius, as the first, added burying the dead in the third century. From the twelfth century there are six and from the thirteenth century there are seven works of mercy in the presentation of Last Judgment in illuminated books, architectural elements, stained glass windows, paraments and furnishing (e.g. door of monastery in Basel). From the fifteenth century, the works of mercy appear in graphics and easel paintings (Bellini, Caravaggio, Murillo). Sometimes the figures of saints replace the helpers and the figure of Christ is portrayed in place of the needy. Such motives have often decorated hospitals

${ }^{40}$ M. M. Wójtowicz, Miłosierdzie w postawie błogosławionego brata Alberta, in: Homo Meditans, v. 5, Miłosierdzie w postawie ludzkiej, ed. W. Słomka, Lublin 1989, p. 217n.

${ }^{41}$ K. S. Frank, Barmherzigkeit. V. Ordensgenossenschaften, in: Lexikon für Theologie und Kirche, v. II, Freiburg im Breisgau 2006, c. 16n; Barmherzige Brüder, Barmherzige Schwestern, in: Lexikon für Theologie und Kirche, v. II, Freiburg im Breisgau 2006, c. 11-13.

${ }^{42}$ The Oxford Dictionary of Christian Art and Architecture, ed. T. Devonshire Jones, P. L. Murray, Oxford 2013, p. 367n. 
and have sometimes shown saints doing works of mercy (Saint Elisabeth of Thuringia). Less often, the personification of mercy (misericordia) can be found, presented as a queen on the throne with a very rich cloak, a crown and nimbus. An example of such art is the cover of the baptismal font in the cathedral of Hildesheim ${ }^{43}$.

The image of Divine Mercy with the inscription "Jesus, I trust in You", which Saint Faustina ordered to be painted on the wish of Jesus expressed during a vision in Płock on 22 February 1931, deserves special attention ${ }^{44}$. The first picture painted by Eugeniusz Kazimirowski in 1934 is in the church in Vilnius formerly dedicated to Holy Trinity and now to Divine Mercy. However, much better known is the image painted by Adolf Hyła in 1944, venerated in Łagiewniki in $\mathrm{Cracow}^{45}$. It is worth mentioning that for centuries the image of merciful Christ from the evangelical scene with Pilate "Ecce Homo" (John $19: 5$ ) has been the subject of worship, as we can see it on the side altar in Korzkiew $^{46}$. Even more often we find paintings of Christ as Misericordia Domini, standing in the tomb and with signs of the Passion, sometimes accompanied by the Sorrowful Mother.

\section{Mercy in the liturgical dimension}

Divine Mercy also has a clear liturgical dimension, because sacraments are a privileged place for experiencing and preaching mercy. Investigations of liturgical books, especially the Roman Missal, show how many prayers include reference toDivine Mercy ${ }^{47}$. One of the oldest penitential acts in the liturgy goes back to the language of the Holy Bible in order to ask for the Lord's Mercy at the beginning of the Holy Mass, by praying "Kyrie eleison, Christe eleison"48.

${ }^{43}$ K. S. Frank, Barmherzigkeit. VI. Ikonographisch, in: Lexikon für Theologie und Kirche, v. II, Freiburg im Breisgau 2006, c. 17; C. Schweicher, Barmherzigkeit, Werke der, in: Lexikon der christlichen Ikonographie, v. 1, Freiburg im Breisgau 1994, c. 245-251.

${ }^{44}$ J. Zabielski, Wydobywanie dobra..., p. 166n.

45 A. Witko, Obraz Bożego Miłosierdzia, Kraków 2004.

${ }^{46}$ Parafia Narodzenia św. Jana Chrzciciela w Korzkwi, ed. Z. Płachta, p. 19.

47 J. Miazek, Bóg Miłosierdzia w modlitwach Mszatu Rzymskiego, in: Homo Meditans, v. 5, Miłosierdzie w postawie ludzkiej, ed. W. Słomka, Lublin 1989, p. 113.

${ }^{48}$ Miłosierdzie, in: Religia. Encyklopedia PWN, ed. T. Gadacz, B. Milerski, Warszawa 2003, p. 47. 
Also in the center of the sacrament of Penance is reconciliation, which springs from unconditional Divine Mercy. That is why Ordo paenitentiae from 1974, begins with: "God, the Father of mercies" has its own time. The day of mercy is every Sunday and all penitential days, but the second Sunday of Easter, has been especially marked as the Feast of Divine Mercy by John Paul II in 2000. Beside days of mercy, the liturgy of the Church also indicate hours of mercy, especially 3 p.m. as the hour of Christ's death. The Church has also received, from the tradition of Old Testament, the idea of Jubilees related to redemptive events of Christ and celebrated in the rhythm of a 50 year cyrcle in connection with the year of mercy ${ }^{50}$.

\section{The pastoral dimension of mercy}

Together with the development of the cult of Divine Mercy, the need of pastoral reflection has been perceived. There have been attempts to answer the question: Whether or why can the idea of Divine Mercy be the content of the new evangelization and so contribute to prevent different threats to mankind? A certain connection between the development of the cult of Divine Mercy and modern challenges of the Church and world in the 20th century has been noted. The idea of Divine Mercy is reflected here as a preventive means against the threats existing in the modern world. Showing various dangers to human dignity, but above all speaking of the Divine Mercy, should inspire the preaching of this truth. That is why this idea is a source of engagement in the evangelization and of participation in the mission of the Church. If the most important content of Christ's teaching is the truth of Divine Mercy, it should be inspiring for pastoral activity, especially homiletics and catechetics ${ }^{51}$.

The idea of mercy also has its place in Canon Law. Mercy is even a canonical rule on the application of law, according to the formulae aequitas canonica and salus animarum, included in canons 19 and 1752 of Code of Canon Law. The last canon says that the salvation of souls must always be the supreme law in

49 J. Servais, Spowiedź sakramentem Ojca Miłosierdzia. Profetyczna intuicja Adrienne von Speyr, in: Kolekcja Communio, nr 15, Bóg bogaty w miłosierdzie, Poznań 2003, p. 210.

${ }^{50}$ R. Forycki, Czas i czasy miłosierdzia, in: Kolekcja Communio, nr 15, Bóg bogaty w miłosierdzie, Poznań 2003, p. 332-335.

51 W. Seremak, Miłosierdzie Boże a nowa ewangelizacja. Znaki czasu, Lublin 2001, p. 398. 
the Church. In this sense, one should resolve the tension between justice and mercy or fidelity to the letter of the law and decision about concrete cases. This recalls Saint Thomas Aquinas' statement: "iustitia sine misericordia crudelitas est; misericordia sine iustitia dissolutio". Some theologians use the example of the rule of economy (оiкоvouí), applied in the juridical practice of Orthodox Church $^{52}$. The connection between theology of mercy and canon law is evident especially in the questions of forgiveness, as it is in the canons concerning the sacrament of penance, penalties and indulgences ${ }^{53}$.

\section{Conclusion}

Mercy is the compassionate care for others, where one takes on the burden of another as one's own. It is an active feature of the virtue of charity, motivated by love. While mercy is often treated as a rather benign term, its power is understood more accurately by looking at it in a scriptural context ${ }^{54}$. The Bible shows God as merciful and requires people to be merciful. This is the basis for discussing mercy from a different perspective in dogmatic and moral theology. Dogmatics shows mercy as the biggest attribute of God, which thanks to redemption took on a Christological character. As the Mother of Mercy is inseparably connected with Christ, the reflection on this attribute also takes place in the mariological context. Ecclesiology, sacramentology and eschatology are also not free from this reflection. In turn, moral theology is interested in mercy, above all, in interpersonal relations showing it as a virtue and duty, which goes far beyond the mere works of mercy. The contemporary reflection on mercy is characterized by a deepening of the personalistic dimension of the bond between mercy and love. The engagement of Christians in the service of mercy, apart from the individual dimension, takes on a wider dimension whenconsidered in the framework of Catholic Social Thought. Among theological sciences, it is Christian spirituality which seems to integrate mostly all the important dimensions of mercy, beginning with an adequate answer to the grace of Divine

${ }^{52}$ T. Schüller, Barmherzigkeit. IV. Kirchenrechtich, in: Lexikon für Theologie und Kirche, v. II, Freiburg im Breisgau 2006, c. 16.

${ }^{53}$ B. Fisichella, Odpust a Boże miłosierdzie, in: Kolekcja Communio, nr 15, Bóg bogaty w miłosierdzie, Poznań 2003, p. 251n.

${ }^{54}$ J. Upton, Mercy, in: The New Dictionary of Catholic Spirituality, ed. M. Downey, Collegeville 1993, c. 653. 
Mercy, through to merciful service to neighbors, which together are an important criterion of striving for Christian holiness. Together with the development of the cult of Divine Mercy one has perceived the necessity of pastoral reflection in which the idea of mercy is an important part of new evangelization, also in the dimension of homiletics and catechetics. The idea of mercy also has its own place in liturgics, canon law and Christian art. Such an efflorescence of reflection on mercy is not accidental and flows from, an almost, instinctive need to look for a more profound sense of human existence.

\section{Bibliography}

Barackman F. H., Practical Christian Theology: Examining the Great Doctrines of the Faith, Grand Rapids MI 2001.

Barmherzige Brüder, Barmherzige Schwestern, in: Lexikon für Theologie und Kirche, v. II, Freiburg im Breisgau 2006, c. 11-13.

Barmherzigkeit, in: Lexikon für Theologie und Kirche, v. II, Freiburg im Breisgau 2006, c. 14-17. Benedict XVI Caritas in veritate.

Benedict XVI, Deus caritas est.

Charles R., Maclaren D., The Social Teaching of Vatican II: Its Origin and Development, San Francisco 1982.

Cox J., Divine Mercy; or, the Riches of God's Pardoning and Paternal Love, London 1838.

Ferdek B., Miłosierdzie, in: Leksykon Duchowości Katolickiej, Lublin-Kraków 2002, p. 519-522.

Grisez G., The Way of the Lord Jesus, v. 2: Living a Christian Life, Quincy 1993.

Homo Meditans, v. 5, Miłosierdzie w postawie ludzkiej, ed. W. Słomka, Lublin 1989.

Kolekcja Communio, nr 15, Bóg bogaty w miłosierdzie, Poznań 2003.

Kongregacja do Spraw Wychowania Katolickiego, Wskazania dotyczace studiów i nauczania doktryny społecznej kościoła w ramach formacji kapłańskiej, 1988.

Krucina J., Komentarz do encykliki Jana Pawła II „,Dives in misericordia”, in: Encyklika Ojca Świętego Jana Pawła II o Bożym Miłosierdziu „,Dives in misericordia”, Wrocław 1996.

Machniak J., Doświadczenie Boga w tajemnicy Jego miłosierdzia u Bt. Siostry Faustyny Kowalskiej, Kraków 1998.

Miłosierdzie, in: Religia. Encyklopedia PWN, ed. T. Gadacz, B. Milerski, Warszawa 2003.

Seremak W., Miłosierdzie Boże a nowa ewangelizacja. Znaki czasu, Lublin 2001.

Nussbaum M.C., Philosophical norms and political attachments: Cicero and Seneca, in: Body and Soul in Ancient Philosophy, ed. D. Frede, B. Reis, Berlin 2009.

Parafia Narodzenia św. Jana Chrzciciela w Korzkwi, ed. Z. Płachta.

Scheeben M. J., Handbuch der Katholischen Dogmatik, v. IV, Freiburg 1948.

Schweicher C., Barmherzigkeit, Werke der, in: Lexikon der christlichen Ikonographie, v. 1, Freiburg im Breisgau 1994, c. 245-251.

Sherman N., Stoic Warriors: The Ancient Philosophy Behind the Military Mind, Oxford 2005. 
Słomka W., Miłosierdzie Boże, in: Leksykon Duchowości Katolickiej, Lublin-Kraków 2002, p. 523.

Słomkowski A., Miłosierdzie Boże we Wcieleniu i Odkupieniu, in: Ewangelia Miłosierdzia, ed. W. Granat, Poznań 1970, p. 49-112.

The Oxford Dictionary of Christian Art and Architecture, ed. T. Devonshire Jones, P. L. Murray, Oxford 2013.

Thomas Aquinas, Summa theologica.

Torretto R., A Divine Mercy Resource: How to Understand the Devotion to Divine Mercy, Bloomington 2010.

Upton J., Mercy, in: The New Dictionary of Catholic Spirituality, ed. M. Downey, Collegeville 1993 , c. $653 \mathrm{n}$.

Veling T.A., In the Name of Mercy: A Meditative Exploration, "Pacifica-Australasian Theological Studies" 22 (June 2009).

Warchoł P., Miłosierny Bóg i miłosierny człowiek. Teologiczna interpretacja miłosierdzia w nauczaniu Jana Pawła II, Wrocław 2007.

Witko A., Obraz Bożego Miłosierdzia, Kraków 2004.

Zabielski J., Wydobywanie dobra. Teologia chrześcijańskiego miłosierdzia, Białystok 2006. 
